REFLECTIONS:

NEUROLOGY AND

THE HUMANITIES

Section Editor

Anne W. McCammon,

MD, FAAN

\title{
A sheep in wolf's clothing
}

\section{A medical student among neurosurgeons}

Dylan Archbold Hufty Alegría, MS

Correspondence to Mr. Alegría:

dylan.alegria@ucsf.edu
"Just don't faint," I think as I stand in the operating room (OR) with my supervising neurosurgery resident. Three anesthesiology residents and an attending sprint around the patient, struggling to insert IVs, draw blood tests, and deliver blood products before his brain herniates through the foramen magnum. I barely notice the activity as physicians and nurses grab tubing, send messengers to the blood bank, and prepare the patient for surgery. Instead, my thoughts are focused on the impending operation. If our patient is to survive, the surgeon will need to relieve the pressure on his brain caused by bleeding made worse by the aspirin and clopidogrel that he has taken for years to prevent a heart attack.

The lines are in. The skull clamp holding the head just so has been adjusted to give the best access to the deepest parts of the patient's brain, its sharp tines penetrating skin to get purchase in bone. Drapes cover every inch of his body, not to protect him from the knives, drills, and staples that will be rested on him in his new role as a table, but to protect his brain from the bacteria that cover his body.

Many medical students have a complex relationship with surgery, simultaneously repulsed by and drawn to the manual task of fixing the human body. Yet there is a simplicity to neurosurgery that stands in stark contrast to the prolonged discussions of patient care by crowds of neurologists walking the hospital halls. There are no families in the OR, and the iodine prep, drapes, and monitors mask the humanity of the malfunctioning body.

A purple marker delineates where we will divide the skin and violate the protective cover of the scalp. The actual incision is as simple as tracing. Almost instantly, purple is replaced by red blood that leaks from the new wound: clean in its own way, but soaking the drapes. The cut skin continues to gently ooze despite cauterization. The patient's handicapped platelets are unable to fulfill their function despite the donated plasma and platelets he has received. The skull comes into view and we slowly push the skin off its smooth surface.

This is where I've fainted before. Two years ago, I was a first-year medical student eager to learn. A trickle of blood escaped a small vessel as I watched from a distance. I found myself on the floor of the OR, concerned not about my health but rather that I'd missed the chance to see that precious organ that houses thoughts. In part, that's why I'm here now with gloves sticky with blood as we drill into the skull to free the brain.

The bone flap is now off, and as we divide the tensely stretched dura we reveal a clot the size of a human palm where we expect the pink undulations of the brain. Unbelievably, the massive clot does not stanch the flow of blood from hidden recesses within the cranium.

Blood overflows the sheets and spills onto the floor. Despite the continuous bleeding, this is a moment of peace during the operation. The pressure has been relieved. The blood is now free to flow out instead of compressing the brain downward.

We spend an hour searching for the leaking vessels, pushing aside outcroppings of temporal lobes and frontal poles to look deep within the skull. Two we find and control with clotting factors, mechanical force, and cautery, fusing brain and blood vessel into a functional dam. We see one more but cannot reach it, and so we are faced with what we feared during the rush from the scanner to the OR. Alan Chen will not survive this catastrophe.

Earlier, I looked on silently as my resident laid the options before Mr. Chen's expectant family in the cramped, impersonal space of the emergency department waiting room. The neurosurgeon asked the son, who had watched his father slip and fall from a ladder minutes earlier, whether we should let his father die or open his head. Alan's wife cried when we explained that he would be unlikely to survive, with or without the operation. His pregnant daughter looked on in stoic disbelief.

My struggle to remain focused and conscious in the OR today is overshadowed by the challenges to come: biting back tears as Mr. Chen's daughter fails to accept that recovery is not possible for her father, watching the family's tired faces say goodbye each time his heart threatens to stop, and finally, witnessing their struggle to understand brain death as it comes to their loved one.

As we replace the bone flap and close the skin, Alan Chen's injury remains unrepaired. My resident 
tells me, "We were treating the family. There was never any chance for this patient." The empathy that I rejected as a liability during the surgery grows into a strength. This surgery failed Mr. Chen and his family. His life was not saved and his family was not soothed by the finely tuned motor skills of the neurosurgeon. I hope my sorrow reflects a greater ability to relate, to comfort, and to explain as the challenge and art of caring for this family continues in the intensive care unit where Alan Chen will die. A clinician's most important efforts occur in waiting rooms, intensive care units, and beyond the walls of the hospital. They are the moments in which the empathic doctor delivers kind words, a quiet space, and a comforting touchessential, effective treatments for the families of those whom the OR cannot save. 


\section{Neurology}

\section{A sheep in wolf's clothing: A medical student among neurosurgeons Dylan Archbold Hufty Alegría \\ Neurology 2013;81;e53-e54 \\ DOI 10.1212/WNL.0b013e3182a2cc5c}

This information is current as of August 26, 2013

\section{Updated Information \& Services}

\section{Subspecialty Collections}

Permissions \& Licensing

Reprints including high resolution figures, can be found at: http://n.neurology.org/content/81/9/e53.full

This article, along with others on similar topics, appears in the following collection(s):

\section{All Education}

http://n.neurology.org/cgi/collection/all_education

Brain death

http://n.neurology.org/cgi/collection/brain_death

Critical care

http://n.neurology.org/cgi/collection/critical_care

Intracerebral hemorrhage

http://n.neurology.org/cgi/collection/intracerebral_hemorrhage

Palliative care

http://n.neurology.org/cgi/collection/palliative_care

Information about reproducing this article in parts (figures,tables) or in its entirety can be found online at:

http://www.neurology.org/about/about_the_journal\#permissions

Information about ordering reprints can be found online:

http://n.neurology.org/subscribers/advertise

Neurology ${ }^{\circledR}$ is the official journal of the American Academy of Neurology. Published continuously since 1951, it is now a weekly with 48 issues per year. Copyright @ 2013 American Academy of Neurology. All rights reserved. Print ISSN: 0028-3878. Online ISSN: 1526-632X.

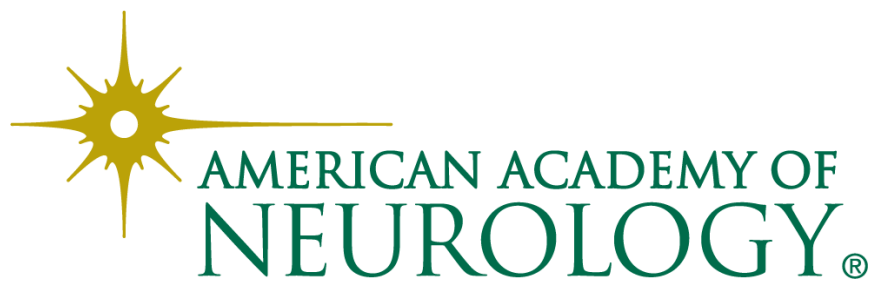

